\title{
Authentic Assessment Instrument: Implementation of Performance-Based Practicum
}

\author{
Risma Agustina ${ }^{1}$ Madziatul Churiyah ${ }^{2}$ \\ Educational Office Administration Program, State University of Malang \\ E-mail: madziatul.churiyah.fe@um.ac.id
}

\begin{abstract}
The purpose of this study was to develop an authentic performance-based assessment instrument in a proper Archival Management course through expert validation and product trials that have been carried out at State University of Malang and meet the National Standards of Higher Education. The research method used Research and Development which was modified into 7 steps with data analysis techniques using mean. Products developed include assessment instruments that were equipped with Student Worksheets, performance observation sheets, and guidelines for scoring criteria. Based on content validation and construct produce works with very decent criteria, the trial conducted by lecturers and students stated that the instrument could be used very easily.
\end{abstract}

Keywords: authentic assessment, performance-based, archival management

\section{INTRODUCTION}

Every university should carry out evaluation activities related to University activities and educational activities (Permenristekdikti, 2014). Standards have been set that must be used to regulate educational activities in universities. National Higher Education Standards include several standards regarding the process, assessment, and content of learning. Assessment standards explain the principles of assessment, techniques and instruments, mechanisms and procedures, implementation, and reporting of assessments (Permenristekdikti, 2014). The principles of the assessment carried out must be authentic, which includes an assessment of processes and results (Permenristekdikti, 2014). Authentic assessment activities are designed to mimic the complexity of "real-world" situations that students might face in professional life, and require the application of a combination skills related to knowledge, skills, and attitudes (Raymond, at all, 2013). Provisions regarding the form and technique of assessment are fully submitted to the lecturer concerned (State University of Malang, 2015: 98). Many educators have not carried out authentic assessments. Previous research stated that out of 210 educators, $24.8 \%$ indicated that they did not use authentic assessment techniques because the authentic assessment required too much time in implementation (28.8\%) Mintah (2003: 166-167).

Every university has a curriculum that is adjusted to the regulations set by the government. Standards regarding learning outcomes of graduates are formulated in the competencies of student graduates, which consist of three 
competencies. One of them is the main competence that is flexible and accommodating to changes very quickly (State University of Malang, 2015). Based on the development of 21st century students, education must also be directed to achieve 21st century competence. Students are required to have the competence to think critically, think creatively, can collaborate and communicate as well as mastery of science and technology (Abidin, 2016: 1). The learning model that can cover 21st century competencies is the REACT (Relating, Experiencing, Actuating, Cooperating, and Transfering) learning method. The REACT learning model emphasizes the provision of information related to previous information already known by students, so students will more easily understand the concepts conveyed by the teacher (Fakhruriza \& Kartika, 2015).

Teaching material must be adjusted to the curriculum applicable to the relevant tertiary institution. Curriculum Structure of the Undergraduate Program consists of several groups of courses. Archival Management course is one of the groups of Craftsmanship Courses which are courses aimed at creating students who are experts in producing works based on knowledge and skills mastered (State University of Malang, 2015). Archival course requires students to master document archiving skills (Pratiwi, et al., 2017: 2). To assess the Archival Management course needs an assessment that focuses on student performance.

Performance assessment can be used to measure the actual performance of students which is inadequate if only measured by an objective test (Purnama, 2014: 25). Performance skills can be divided into oral and demonstration skills (Abidin, 2016: 241). Evaluation of the demonstration can be in the form of simulation assessment (Yusuf, 2015: 299). Performance tests are carried out using actual tools and ask students to realize actual tasks that represent the overall performance to be assessed to determine the skills achievement (Susila, 2012: 5). One source of learning that can be used within the scope of Higher Education is Student Worksheets (LKM) (Dedy, et al., 2012: 109). Student Worksheets are prepared independently by the lecturer so that students become active in learning (Mairing, 2013: 55). The tasks in the LKM can be theoretical or practical. These LKM teaching materials learners obtain teaching materials following predetermined basic competencies.

\section{METHOD}

The research and development method used was Research and Development by Sugiyono which has been modified into 7 steps, which include (1) potential and problems, (2) data collection, (3) product design, (4) design validation, (5) revision design, (6) product trials, and (7) product revisions. The data collected was qualitative and quantitative data through interviews, observations, and questionnaires to validators and experimental subjects (Pratiwi, et al., 2017: 4). Interview and observation activities were carried out with the Head of the Undegraduate of Educational Office Administration Program and lecturers supporting the Archival Management course for problem finding and supporting data collection. Researchers also conducted a study of the Minister of Research, Technology and Higher Education Regulation number 44 of 2015 concerning the National Standards of Higher Education and the curriculum at State University of Malang in 2015/2016. The product developed in the form of Student Worksheets 
(LKM) which was developed with the stages compiled by Plomp (in Prastiti, 2015: 65) was equipped with an observation sheet and guidelines for scoring criteria. Content and construct validation activities were carried out by management lecturers at State University of Malang with content validator qualifications having a minimum service period of 5 years and minimum education Undegraduate of Educational Office Administration and constructor validator qualifications having minimum education criteria S2 and a minimum of 5 years teaching experience (Sudaryono, et al, 2013: 106). The product was then tested on lecturers and students. The lecturer trial subjects consisted of 4 Filing Management lecturers as users of the assessment instruments and the student trial subjects consisted of 37 students of Filing Management courses as parties who measured the readability of the Student Worksheet. The data analysis technique used was the mean and was categorized using validity levels (Akbar, 2013: 82).

\section{RESULT \& DISCUSSION}

The product of research and development is in the form of authentic performancebased assessment instruments in Archival Management Course (a study of students in the filing of management courses in Educational Office Administration Management Department at State University of Malang) consisted of several sections. These sections were instructions for use, psychomotor assessment instructions, psychomotor assessment instrument grids, student worksheets (LKM), observation sheets, and guidelines for scoring criteria. Instrument products were divided into 2 parts which were for lecturers and students. The instrument for lecturers were accompanied by a performance observation sheet and guidelines for scoring criteria. Some of the strengths of this authentic performance-based assessment instrument were making it easier for lecturers to make authentic assessments, makes it easier for students to learn independently, and gets mastery learning. Some weaknesses in this instrument were the complex aspects of valuation that require a long time in the assessment process.

The results of construct validation showed that the assessment instrument had a construction with "very feasible" criteria. This showed that the measurement tools that had been arranged showed results that were under the theory (Widodo, 2006: 3).

Table 1 Quantitative Data on Validation of Constructive Psychomotor Aspects

\begin{tabular}{clccc}
\hline No. & \multicolumn{1}{c}{ Assessment Indicator } & Tse & P & Criteria \\
\hline 1 & $\begin{array}{l}\text { The performance task directs students to } \\
\text { demonstrate learning outcomes }\end{array}$ & 4 & $80 \%$ & Valid \\
\hline 2 & $\begin{array}{l}\text { The task performance is following the level of } \\
\text { student development }\end{array}$ & 4 & $80 \%$ & Valid \\
\hline 3 & There is a timeframe for working on assignments & 5 & $100 \%$ & Very Valid \\
\hline 4 & Rubrics can be used in assessing student abilities & 4 & $80 \%$ & Valid \\
\hline 5 & Rubrics can be used to map student abilities & 4 & $80 \%$ & Valid \\
\hline 6 & $\begin{array}{l}\text { Aspects to be assessed in the performance } \\
\text { appraisal is complete and appropriate }\end{array}$ & 4 & $80 \%$ & Valid \\
\hline 7 & Rubric assessment clearly how to use it & 5 & $100 \%$ & Very Valid \\
\hline
\end{tabular}




\begin{tabular}{clrrc}
\hline 8 & $\begin{array}{l}\text { The evaluation criteria for each choice on the } \\
\text { indicator are clear }\end{array}$ & 5 & $100 \%$ & Very Valid \\
\hline 9 & Assessment criteria are arranged in detail & 4 & $80 \%$ & Valid \\
\hline 10 & Scoring interval are adequate & 4 & $80 \%$ & Valid \\
\hline 11 & $\begin{array}{l}\text { Ability to be assessed is not too much and can be } \\
\text { observed }\end{array}$ & 5 & $100 \%$ & Very Valid \\
\hline 12 & $\begin{array}{l}\text { The instrument is implemented in an integrated } \\
\text { manner with learning }\end{array}$ & 4 & $80 \%$ & Valid \\
\hline & Mean & $\mathbf{4 , 3 3}$ & $\mathbf{8 7 \%}$ & Very Valid \\
\hline
\end{tabular}

Source: Processed by Researcher

Content validation showed that the contents of the instrument had the criteria "very feasible". This showed that the product developed in terms of content was following the intended purpose (Hendryadi, 2017: 171).

Table 2 Quantitative Data on Validation Results for the Psychomotor Aspect

\begin{tabular}{|c|c|c|c|c|}
\hline No. & Assessment Indicator & Tse & $\mathbf{P}$ & Criteria \\
\hline 1 & $\begin{array}{l}\text { The assessment instruments are following the } \\
\text { indicators/BC }\end{array}$ & 4 & $80 \%$ & Valid \\
\hline 2 & $\begin{array}{l}\text { The aspects measured are following the learning } \\
\text { objectives }\end{array}$ & 4 & $80 \%$ & Valid \\
\hline 3 & $\begin{array}{l}\text { Directions for answering and filling the instrument } \\
\text { are clear/easy to understand }\end{array}$ & 4 & $80 \%$ & Valid \\
\hline 4 & $\begin{array}{l}\text { The assessment indicators on the assessment } \\
\text { instruments are clear/easy to understand }\end{array}$ & 4 & $80 \%$ & Valid \\
\hline 5 & $\begin{array}{l}\text { Work steps on the Student Worksheet are } \\
\text { coherent }\end{array}$ & 4 & $80 \%$ & Valid \\
\hline 6 & The language used is effective & 5 & $100 \%$ & Very Valid \\
\hline 7 & $\begin{array}{l}\text { The format of the instrument to be used is } \\
\text { interesting }\end{array}$ & 5 & $100 \%$ & Very Valid \\
\hline 8 & The language used is communicative & 5 & $100 \%$ & Very Valid \\
\hline 9 & The language used is according to EYD & 5 & $100 \%$ & Very Valid \\
\hline \multirow[t]{2}{*}{10} & $\begin{array}{l}\text { The placement on the assessment instrument is } \\
\text { clear/easy to understand }\end{array}$ & 4 & $80 \%$ & Valid \\
\hline & Mean & 4,4 & $\mathbf{8 8} \%$ & Very Valid \\
\hline
\end{tabular}

Source: Processed by Researcher

After the product was validated, the next step was to conduct a limited trial test to lecturers and students. The results of limited trials of lecturers indicated that the instrument could be used with the criteria of "very feasible" with a percentage of $90 \%$. This proves that lecturers could use assessment instruments very easily and appropriately

Table 3 Quantitative Data on Trial Results of Psychomotor Aspects

\begin{tabular}{lllll}
\hline No. & Assessment Indicator & Tse & $P$ & Criteria \\
\hline
\end{tabular}




\begin{tabular}{clccc}
\hline 1 & $\begin{array}{l}\text { Systematics is presented in an orderly and } \\
\text { systematic manner }\end{array}$ & 17 & $85 \%$ & Very Valid \\
\hline 2 & Systematics of writing activity objectives are clear & 18 & $90 \%$ & Very Valid \\
\hline 3 & Systematics of writing instructions are clear & 19 & $95 \%$ & Very Valid \\
\hline \multirow{2}{*}{4} & $\begin{array}{l}\text { Suitability of the problem with the development of } \\
\text { students }\end{array}$ & 19 & $95 \%$ & Very Valid \\
\hline 5 & Activity stimulates students' activity & 19 & $95 \%$ & Very Valid \\
\hline 6 & Enough pictures and illustrations & 19 & $95 \%$ & Very Valid \\
\hline 7 & The language used is communicative & 19 & $95 \%$ & Very Valid \\
\hline 8 & The language used is according to EYD & 17 & $85 \%$ & Very Valid \\
\hline 9 & Language is following students' development & 18 & $90 \%$ & Very Valid \\
\hline 10 & The language used is clear and unambiguous & 18 & $90 \%$ & Very Valid \\
\hline 11 & The language used is easy to understand & 18 & $90 \%$ & Very Valid \\
\hline 12 & Easy to use & 17 & $85 \%$ & Very Valid \\
\hline 13 & Simplify learning & 19 & $95 \%$ & Very Valid \\
\hline 14 & Adequate time allocation & 16 & $80 \%$ & Valid \\
\hline & & $\mathbf{1 8 , 0}$ & $\mathbf{9 0} \%$ & Very Valid \\
\hline
\end{tabular}

Source: Processed by Researcher

Trial activities were limited to students as users of student worksheets (LKM) stated that students could very easily understand assignments in worksheets with a percentage of $84 \%$.

Table 4 Quantitative Data on Student Outcomes of Psychomotor Aspects

\begin{tabular}{|c|c|c|c|c|}
\hline No. & Indikator Penilaian & Tse & $\mathbf{P}$ & Kriteria \\
\hline 1 & Clear work instructions & 158 & $85 \%$ & Very Valid \\
\hline 2 & Activity stimulates students' activity & 157 & $85 \%$ & Very Valid \\
\hline 3 & Enough pictures and illustrations & 145 & $78 \%$ & Valid \\
\hline 4 & The language used is according to EYD & 162 & $88 \%$ & Very Valid \\
\hline 5 & The language used is easy to understand & 164 & $89 \%$ & Very Valid \\
\hline 6 & Student worksheets (LKM) are easy to use & 152 & $82 \%$ & Very Valid \\
\hline 7 & Student worksheets (LKM) facilitates learning & 153 & $83 \%$ & Very Valid \\
\hline \multirow[t]{2}{*}{8} & Allocation of time is following the tasks assigned & 150 & $81 \%$ & Very Valid \\
\hline & Mean & 155,1 & $\mathbf{8 4} \%$ & Very Valid \\
\hline
\end{tabular}

Source: Processed by Researcher

Implementation of assessment instruments was an activity of trying out Student Worksheets to the tried subjects which was students. The results of using an authentic performance-based assessment instrument that was tested on a trial subject of 37 students showed that each student was able to complete a task $100 \%$ complete. Based on student learning outcomes, it could be concluded that by using Student Worksheets that had been arranged, performance observation sheets, and guidelines for scoring criteria students could complete with an average value of 90 , and all students could complete teaching materials very well. In addition, each stage in this instrument could be passed with a very good value. The following were the 
results of field trials of performance-based authentic assessment instruments in the Archival Management course shown in Table 5.

Table 5 Data on Field Test Results of Student LKM Users

\begin{tabular}{|c|c|c|c|c|c|}
\hline \multirow[t]{2}{*}{ Aspect } & \multirow[t]{2}{*}{$\begin{array}{c}\text { Average } \\
\text { Student } \\
\text { Grades }\end{array}$} & \multicolumn{2}{|c|}{$\begin{array}{c}\text { Competent / } \\
\text { Completed / } \\
\text { Good } \\
\end{array}$} & \multicolumn{2}{|c|}{$\begin{array}{c}\text { Incompetent / Not } \\
\text { Complete / Not or } \\
\text { Poor }\end{array}$} \\
\hline & & f & $\%$ & $\mathbf{f}$ & $\%$ \\
\hline Work preparation & 97 & 37 & $100 \%$ & - & - \\
\hline $\begin{array}{l}\text { Process (Systematics and } \\
\text { How it Works) }\end{array}$ & 91 & 37 & $100 \%$ & - & - \\
\hline Work result & 89 & 37 & $100 \%$ & - & - \\
\hline Work attitude & 86 & 37 & $100 \%$ & - & - \\
\hline Settlement Time & 87 & 37 & $100 \%$ & - & - \\
\hline Average Student Grades & 90 & 37 & $100 \%$ & - & - \\
\hline
\end{tabular}

Source: Processed by Researcher

This research and development resulted a product in the form of an authentic performance-based assessment instrument in the Archival Management Course. This assessment was focused on the assessment of psychomotor aspects, according to the characteristics of the Archival Management course which was included in the type of Craftsmanship Courses that required students to make a work following their field of expertise (State University of Malang, 2015:69). Assessment is an assessment activity that uses 3P, namely performance, portfolio, and product (Dori, 2003). The best and most common practice in class assessments is making authentic judgments. The assessment instruments compiled included Student Worksheets (LKM) as teaching materials (Wirda, et al., 2018: 165), observation sheets which consisted of the preparation stage until the time of completion of the product being compiled (Setiadi, 2016: 174), as well as the ways of extracting equipped with guidelines on scoring criteria (Sumaryanta, 2015: 181). LKM contains instructional instructions, learning objectives, things that need to be known before practicing, examples of work steps accompanied by material, and practical steps (Septia, 2014: 81). Student Worksheets, performance observation sheets, and guidelines on scoring criteria are a package arranged to complement each other. The assessment aspects in the performance observation sheet are based on the Student Worksheet and the assessment criteria are arranged based on the aspects in the performance observation sheet, starting from the preparation stage to the execution time.

The development of this valuation instrument product has several parts which are very supportive of one another (Baartman et al., 2006). These sections include (1) psychomotor assessment instructions, (2) instructions for use, (3) outline psychomotor assessment instruments, (3) student worksheets (LKM), (4) observation sheets, and (5) guidelines scoring criteria. Instrument products are divided into 2 parts, for lecturers and students. The instrument for lecturers is accompanied by a performance observation sheet and guidelines for scoring criteria. The psychomotor assessment guideline contains three subpoints, namely the psychomotor assessment which contains the assessment formula at each stage of the learning activities from the preparation stage, work process, work results, 
attitude, and work time; final value calculation which contains the formula for adding values at each stage; and processing psychomotor values that contain predicates following the scores obtained by students (Aizpurua et al., 2018; Baartman et al., 2006). Directions for the use of psychomotor assessment instruments include course learning outcomes (CPMK), distribution of student worksheets for lecturers and students, as well as learning activities to be carried out. Each CPMK is explained about the instructions for use. A grid of psychomotor assessment instruments is also arranged in each CPMK. It contains graduate achievement standards (SCPL), main activities, psychomotor indicators that contain aspects that will be assessed at each stage of learning activities, and authentic assessment techniques consisting of class presentations, products, and projects.

Student worksheets are arranged based on CPMK. CPMK 1 consists of $1 \mathrm{LKM}$, CPMK 2 consists of $1 \mathrm{LKM}$, and CPMK 3 consists of $9 \mathrm{LKM}$. The student worksheet contains the name of the course, the title of the learning activity, indicators, semester description, learning objectives, and the time allocation was given. LKM also contains instructional instructions, containing learning activities that must be carried out by lecturers and students, things that need to be known before doing practice, practical activities carried out in outline, examples of practical steps accompanied by teaching materials, questions, practice instructions, materials and tools, and practical steps (Zahro et al., 2017: 68). The performance observation sheet contains student self-data (Name, NIM, and Offering), assessment subcomponents at each stage of learning activities, and competency achievement scores that contain a scale of 1-5. How to fill in is done by writing a checklist in the column provided. The score obtained is multiplied by the percentage of the weight that has been adjusted to the level of importance of each stage. The scoring criteria guideline contains assessment subcomponents at each stage of the learning activities which are clarified by providing indicators for scores ranging from 1-5. The other supporting part is a table of contents that contains the main part accompanied by a page, a list of pictures contained in the product, general instructions containing the division of practical learning activities and presentations as well as an explanation of the number of LKM in each Course Learning Achievement, and REACT (Relating, Experiencing, Applying, Cooperating, and Transfering) learning activities which contains the stages of REACT learning.

Several advantages gained in using this instrument are it can increase the learning independence of students following Susanti's research (2017: 1369) argued that by using LKM the learning independence of students rises to $89.4 \%$ and 94.01\%. LKM that are equipped with practical instructions and examples of practical steps in addition to increasing independence also create mastery learning (Baartman et al., 2006; Cotrus and Stanciu, 2014) because students can learn anytime and anywhere. The disadvantage of authentic assessment instruments is that they take a long time to process. Following research by Mintah (2003: 166-167) stated that $28.8 \%$ did not carry out authentic assessments because the time required for the assessment was very long and the study by Setiawati et al. (2017: 144 ), found that the obstacle faced by educators is there are too many components that must be assessed so it requires considerable time if the assessment is done ideally. 


\section{CONCLUSION}

Research and development produce authentic performance-based assessment instruments in the Archival Management course, which is equipped with Student Worksheets. Assessment instruments can facilitate educators in carrying out authentic assessments by providing indicators on each student's answer (Darmawati, et al., 2016: 67). Student Worksheets can increase students' learning independence (Susanti, 2017: 1369). The results of the contents and construct validation stated that the instruments that had been prepared had very decent criteria. Lecturers and students could use assessment instruments very easily. Some students commented that the conceptualized material such as examples of work steps greatly facilitates the task. Suggestions for the use of this product so that the observer is given direction before assessing how to use the product, the LKM is given before the learning activity, and the lecturer carries out the activity according to the REACT learning model. Suggestions for dissemination so that the product is journalized and used in State University of Malang. Suggestions for further products so that the trial activities are carried out with more respondents, LKM are arranged more complex in each course learning achievement, systematically more attractive, simplification of aspects that are the focus of assessment, increasing product effectiveness and efficiency, developing authentic assessment instruments in Archival Management II courses and other subjects.

\section{REFERENCES}

Abidin, Y., 2016. Revitalisasi Penilaian Pembelajaran dalam Konteks Pendidikan Multilitersi Abad Ke-21. Bandung: Refika Aditama.

Aizpurua, A., Lizaso, I., \& Iturbe, I., 2018. Learning Strategies and Reasoning Skills of University Students. Rev. Psicodidáct. Engl. Ed 23, 110-116. https://doi.org/10.1016/j.psicoe.2018.02.002.

Akbar, S., 2013. Instrumen Perangkat Pembelajaran. Bandung: Remaja Rosdakarya.

Baartman, L.K.J., Bastiaens, T.J., Kirschner, P.A., \& van der Vleuten, C.P.M., 2006. The wheel of competency assessment: Presenting quality criteria for competency assessment programs. Stud. Educ. Eval. 32, 153-170. https://doi.org/10.1016/j.stueduc.2006.04.006.

Cotrus, A., \& Stanciu, C., 2014. A Study on Dynamic Assessment Techniques, as a Method of Obtaining a High Level of Learning Potential, Untapped by Conventional Assessment. Procedia - Soc. Behav. Sci., 5th World Conference on Educational Sciences 116, 2616-2619. https://doi.org/10.1016/j.sbspro.2014.01.622.

Darmawati, Yusuf, Y., Wentymeses, F. 2016. Instrumen Penilaian Autentik pada Pembelajaran IPA Kelas VII SMP di Pekanbaru. Jurnal Biogenesis, 12(2), 6570. https://biogenesis.ejournal.unri.ac.id/index.php/JPSB/article/view/5105 .

Dedy, E., Mulyana, E., \& Sudihartinih, E., 2012. Pengembangan Bahan Ajar Kalkulus Vektor Berdasarkan Model Pembelajaran Matematika Knisley Sebagai Upaya Meningkatkan Kompetensi Matematika Mahasiswa. Pythagoras Jurnal Matematika Pendidikan Matematika, 7(1), 101-112. https://journal.uny.ac. id/index.php/pythagoras/article/view/2840/2356. 
Dori, Y.J., 2003. Student's Performance in the Matriculation 2000 Project. Journal of Research in Science Teaching, 40(1), 34-52. http://onlinelibrary.wiley.com/doi/abs/10.1002/tea.10059.

Fakhruriza, O., \& Kartika, I., 2015. Keefektifan Model Pembelajaran Relating, Experiencing, Applying, Cooperating, Transferring (REACT) untuk Meningkatkan Hasil Belajar Siswa SMP pada Materi Kalor. JRKPF UAD, 2(2), 54-57. journal.uad.ac.id/index.php/JRKPF/article/view/3250.

Hendryadi., 2017. Validitas Isi: Tahap Awal Pengembangan Kuisioner. Jurnal Riset Manajemen dan Bisnis (JRMB) Fakultas Ekonomi UNIAT, 2(2), 169-178. jrmb.ejournal-feuniat.net/index.php/JRMB/article/view/47/36.

Mairing, J. P., 2013. Pengembangan Lembar Kerja Mahasiswa (LKM) Berbasis Masalah dan Proyek pada Mata Kuliah Analisis Data. Jurnal Pendidikan, 14(2), 55-64. http://ilp.ut.ac.id/index.php/JP/article/view/166.

Mintah, J.K., 2003. Authentic Assessment in Physical Education: Prevalence of Use and Perceived Impact on Students' Self-Concept, Motivation, and Skill Achievement. Measurement In Physical Education And Exercise Science, 7(3), 161-174. http://www.tandfonline.com/page/terms-and-conditions.

Peraturan Menteri Riset, Teknologi dan Pendidikan TInggi Republik Indonesia Nomor 44 Tahun 2015 tentang Standar Nasional Pendidikan Tinggi. Fapereta UGM. (Online), (faperta.ugm.ac.id).

Peraturan Pemerintah Republik Indonesia Nomor 4 Tahun 2014 tentang Penyelenggaraan Pendidikan Tinggi dan Pengelolaan Perguruan Tinggi. Isiska (Online), (http://isi-ska.ac.id).

Pratiwi, D., Arief, M., \& Churiyah, M., 2017. The Development of Performance-Based Model Authenthic Assessment on Archival Subject. International Research Conference on Economics and Business Facing Future Economics: Challenges and Perspective, 2(1) 106. http://irceb.org/proceedings-2017/Education/.

Purnama, R. D. A., 2014. Penilaian Performa dalam Pembelajaran SAINS. Jurnal Pendidikan, 15(1), 22-30. http://jurnal.ut.ac.id/index.php/JP/article/view/ 212.

Raymond, J. E., Homer, C. S. E., Smith, R., \& Gray, J. E., 2013. Learning Through Authentic Assessment: An Evaluation of A New Development in the Undergraduate Midwifery Curriculum. Nurse Education in Practice, 13(5), 471-476. https://doi.org/10.1016/j.nepr.2012.10.006.

Septia, T., Yunita, A., 2014. Praktikalitas Lembar Kerja Mahasiswa (LKM) Struktur Aljabar di STKIP PGRI Sumatera Barat. Jurnal LEMMA 1(1), 76-84. Dari http://ejournal.stkip-pgri-sumbar.ac.id.

Setiadi, H., 2016. Pelaksanaan Penilaian pada Kurikulum 2013. Jurnal Penelitian dan Evaluasi Pendidikan, 20(2), 166-178.

https://journal.uny.ac.id/index.php/jpep/article /viewFile/7173/8446.

Setiawati., Kismini, E., \& Rochana, T., 2017. Penggunaan Asesmen Autentik oleh Guru Sosiologi di SMA Negeri 1 Boja (Pokok Bahasan Materi Pembentukan Kelompok Sosial). Solidarity, 6(2), 135-147. https://journal.unnes.ac.id/sju/ index.php/solidarity/article/view/19558/9278.

Sudaryono., Margono, G., \& Rahayu, W., 2012. Pengembangan Instrumen Penelitian Pendidikan. Yogyakarta: Graha Ilmu. 
Sumaryanta., 2015. Pedoman Penskoran. Indonesian Digital Journal of Mathematics and Education, 2(3), 191'190. Dari idealmathedu.p4tkmatematika.org/wpcontent/uploads/2016/01/6_Sumaryanta.pdf

Sugiyono., 2016. Metode Penelitian Kuantitatif, Kualitatif, dan $R$ \& D. Bandung: Alfabeta.

Susanti, V.D., 2017. Pengembangan Lembar Kerja Mahasiswa (LKM) untuk Menumbuhkan Kemandirian Mahasiswa pada Mata Kuliah Analisis Numerik. Jurnal Penelitian Pendidikan, 9(1), 1311-1374. http://ejournal.stkippacitan. ac.iid/index.php/jpp/article/view/129.

Susila, I. K., 2012. Pengembangan Instrumen PenilaianUnjuk Kerja (Performance Assessment) Laboratorium Mata Pelajaran Fisika Sesuai Kurikulum Tingkat Satuan Pendidikan SMA Kelas X di Kabupaten Gianyar. Jurnal Penelitian dan Evaluasi Pendidikan Indonesia, 2(2), 1-15. http://oldpasca.undiksha. ac.id/ejournal/index.php/jurnal_ep/article/view/375.

Universitas Negeri Malang., 2015. Pedoman Pendidikan UM tahun akademik 2015/2016. Malang: Biro Akademik, Kemahasiswaan, Perencanaan, Informasi, dan Kerjasama.

Widodo, P. B., 2006. Reliabilitas dan Validitas Konstruk Skala Konsep Diri untuk Mahasiswa Indonesia. Jurnal Psikologi Universitas Diponegoro, 3(1), 1-9. https://ejournal.undip.ac.id/index.php/psikologi/article/viewFile/686/55 0.

Wirda, M. A., Rosni, Berutu, N., \& Rahmad, R., 2018. Pengembangan Lembar Kerja Mahasiswa (LKM) Berbasis Project pada Mata Kuliah Evaluasi Hasil Belajar Geografi TA 2017/2018. Jurnal Geografi, 10(2), 174-175. https://jurnal.unimed.ac.id/2012/index.php/geo/article/download/10443 /9434.

Yusuf, A.M., 2015. Asesmen dan Evaluasi Pendidikan Pilar Peyedia Informasi dan Kegiatan Pengendalian Mutu Pendidikan. Jakarta: Prenadamedia Group.

Zahro, U. L., Serevina, V., \& Astra I. M., 2017. Pengembangan Lembar Kerja Siswa (LKS) Fisika dengan Menggunakan Strategi Relating, Experiencing, Applying, Cooperating, Transfering (REACT) Berbasis Karakter pada Pokok Bahasan Hukum Newton. Jurnal Wahana Pendidikan Fisika, 2(1), 63-68. ejournal.upi.edu/index.php/WapFi/article/download/4906/pdf. 